\title{
Competitiveness of Indonesia's Turmeric Commodity in International Market: Using RCA and EPD Approaches
}

\author{
Ni Desak Gede Putri Megagita ${ }^{1}$, Zainal Abidin ${ }^{1 *}$, Ktut Murniati ${ }^{1}$ \\ ${ }^{1}$ Department of Agribusiness, Faculty of Agriculture, University of Lampung, Jalan Soemantri \\ Brodjonegoro 1, Bandar Lampung, 35145 \\ *Email: zainal.abidin@fp.unila.ac.id
}

\begin{abstract}
Turmeric has been known as one of Indonesia's prospective commodities for years. It has great value for food, medicine, and pharmaceutical purposes. Turmeric production of Indonesia from 2008 to 2019 has been increasing since the harvested area for turmeric had been extended. This progress indicated that Indonesia's turmeric may have a great chance to develop. This research aimed to measure the competitiveness of Indonesia's turmeric in the international market. Competitiveness analysis employs Revealed Comparative Advantage (RCA) and Export Product Dynamic (EPD). By using RCA analysis, the study suggested that Indonesia's turmeric commodity is highly competitive in global market. Using EPD calculation, Indonesia export on turmeric acid is in falling star position.
\end{abstract}

Keywords: competitiveness; export product dynamic (EPD); revealed comparative advantage (RCA); turmeric

Disubmit : 10 Juli 2021 Diterima: 19 Juli 2021 Disetujui : 29 Oktober 2021

\section{INTRODUCTION}

Indonesia as an agricultural country has great potential in its natural resources. Plenty agri-products are exportable, one of which is a biopharmaceutical plant. Biopharmaceutical plants generally consist of thirteen types of plants, namely ginger, galangal, cutcherry, bitter ginger, curcuma, Curcuma aeruginosa, Strobilanthes crispa, sweet flag, cardamom, fingerroot, noni, Green chiretta, and turmeric (Zamroni and Munadi, 2017).

Turmeric production in Indonesia is mostly used to meet the needs of the domestic industry for turmeric production in Indonesia. Another part of Indonesian turmeric production is used to meet the needs of foreign industries (exports). Production of turmeric in Indonesia also affects the export of Indonesian turmeric to international markets, production, harvest area, and productivity is provided Table 1.

Table 1 suggests that Indonesia's turmeric exports to the global market has been fluctuating. The production of Indonesia's turmeric has been fluctuative could be caused of some factors that influence it. Export, Import and harvest area variable are affecting the production volume of turmeric (Listyana, 2018). The biggest volume of turmeric was in 2018 reaching more than 200 thousand tonnes. The biggest export countries destination of Indonesian turmeric exports are included: India, Malaysia, Singapore, the United States, China (Taipei), England, South Korea, and Vietnam. 
Penulis : Ni Desak Gede dkk Competitiveness of Indonesia’s Turmeric Commodity ....

Table 1. Indonesia's turmeric production, harvest area, dan productivity (BPS, 2010-2019)

\begin{tabular}{lccc}
\hline Year & Harvest area (ha) & Production (ton) & Productivity (ton/ha) \\
\hline $\mathbf{2 0 1 0}$ & 4.558 & 107.375 & 2,35 \\
$\mathbf{2 0 1 1}$ & 3.954 & 84.803 & 2,14 \\
$\mathbf{2 0 1 2}$ & 4.939 & 96.979 & 1,96 \\
$\mathbf{2 0 1 3}$ & 5.429 & 120.726 & 2,22 \\
$\mathbf{2 0 1 4}$ & 5.046 & 112.088 & 2,22 \\
$\mathbf{2 0 1 5}$ & 5.668 & 113.101 & 1,99 \\
$\mathbf{2 0 1 6}$ & 5.485 & 107.784 & 1,96 \\
$\mathbf{2 0 1 7}$ & 6.287 & 128.339 & 2,04 \\
$\mathbf{2 0 1 8}$ & 7.297 & 203.458 & 2,78 \\
$\mathbf{2 0 1 9}$ & 8.100 & 190.909 & 2,35
\end{tabular}

Indonesian turmeric consumption data is still not available, so the Indonesian turmeric consumption data is obtained from the calculation of the difference between turmeric production in Indonesia and the export volume of Indonesian turmeric, then added up with the volume of turmeric imports in Indonesia. Based on Table 2, the statistics on turmeric consumption in Indonesia has been volatile, but turmeric production in Indonesia can still meet Indonesian domestic demand. This can be seen from the gap in 20102019 between turmeric production in Indonesia and the volume of turmeric consumption in Indonesia. Although surplus of production is not so big, it is still opportunity to maintain export to global market. Turmeric consumption in Indonesia and Indonesia's turmeric export volume 2009 - 2019 served on Table 2.

Table 2. Turmeric consumption in Indonesia and Indonesia's turmeric export volume 2009 -2019 (BPS, 2010-2019)

\begin{tabular}{ccc}
\hline Year & Turmeric consumption in Indonesia (ton) & Export volume (ton) \\
\hline 2009 & 121.395 & 2.693 \\
2010 & 101.271 & 7.545 \\
2011 & 82.190 & 4.502 \\
2012 & 95.828 & 2.125 \\
2013 & 118.795 & 2.101 \\
2014 & 108.353 & 4.515 \\
2015 & 104.521 & 10.499 \\
2016 & 99.543 & 11.708 \\
2017 & 120.600 & 11.313 \\
2018 & 194.194 & 12.958 \\
2019 & 184.530 & 7.765 \\
\hline
\end{tabular}

In the international trade of turmeric commodities, Indonesia is not the only country that is an exporter of turmeric. There are at least five countries that also sell turmeric to the international market. These countries include India, Myanmar, Vietnam, Ethiopia, and the Netherlands. But uniquely, Indonesia as an exporter of turmeric, is also a country that imports turmeric from abroad. In fact, with the existence of other turmeric producing countries, the development of turmeric exports in the long term will largely be determined by improving the quality of the commodity and its competitiveness.

\section{RESEARCH METHODS}

\section{Method of Location Determination}

This research was conducted in Indonesia based on the consideration that Indonesia has a large potential for export of biopharmaceuticals, especially in the turmeric commodity (Yolandika, Nurmalina and Suharno, 
2017) .

\section{Methods of Data Collection}

The data used in this study is secondary data (time series) which is periodic data for 10 years, from 2009 to 2019 with data per year. The data needed in the research on the competitiveness of turmeric exports in Indonesia is the export value of turmeric in Indonesia and the world, the total export value in Indonesia and the total export value of all world commodities obtained from the Trademap website. Another data used in this research is secondary data obtained from related agencies, such as the Indonesian Central Statistics Agency, the Directorate General of Horticulture, and the Trademap website. To complete the required data, data and information obtained from journals, articles, internet, reference books, and studies from previous studies are used

\section{Data Analysis}

In order to find out the competitiveness of Indonesia's turmeric in international market, then this research used Revealed Comparative Advantage (RCA) and Export Product Dynamic (EPD).

1. Revealed Comparative Advantage (RCA)

RCA is index that expresses comparative advantage and is a comparison between the export share of a commodity in the country's total exports compared to the export market of the same commodity in total world exports (Basri and Munandar, 2010). According to Tambunan (2001), the formula of RCA is :

$$
R C A=\frac{X i j / X i t}{W j / W t}
$$

Description:

RCA : RCA value

$\mathrm{Xij}$ : Export value of Indonesia's turmeric to the international market

Xit : Export value of all Indonesia's commodities to the international market

Wij : Export value of world's turmeric

Wit :Export value of all commodities from all countries

If the result of the RCA index is greater than 1, it indicates that Indonesia's turmeric has higher comparative advantage than the other producer countries of turmeric in the world. Otherwise, it means that the comparative advantage of Indonesia's turmeric is poor, less than world's competitiveness (Putra et al., 2015).

There were so many researcher who have using RCA for the competitiveness anylisis. Utami (2018) was using RCA analysis for analyzing the competitiveness of Indonesia's coffee beans export to the international market. Another researcher that using RCA was Apriansyah, 2019 in his research to analyze the competitiveness of Indonesia's natural rubber.

\section{Export Product Dynamic (EPD)}

EPD analysis method is used to measure the dynamics of the Indonesian turmeric market position in the international market. The EPD matrix uses market attractiveness as the horizontal or X-axis and business strength as the vertical or Y-axis. Market attractiveness is measured based on demand growth, while business strength is measured by the growth in market earnings or market share. According to Bappenas (2009), the formula of EPD are :

$$
\frac{\sum_{t=1}^{\mathrm{X}-\mathrm{axis}}\left(\frac{\mathrm{x}_{i j}}{\mathrm{w}_{i j}}\right)_{t} \mathrm{x} 100 \%-\sum_{t=1}^{t}\left(\frac{\mathrm{x}_{i j}}{\mathrm{w}_{i j}}\right)_{t-1} \mathrm{x} 100 \%}{T}
$$


Penulis : Ni Desak Gede dkk Competitiveness of Indonesia's Turmeric Commodity ....

Y-axis

$\frac{\sum_{t=1}^{t}\left(\frac{\mathrm{x}_{t}}{\mathrm{w}_{t}}\right)_{t} \times 100 \%-\sum_{t=1}^{t}\left(\frac{\mathrm{x}_{t}}{\mathrm{w}_{t}}\right)_{t-1} \mathrm{x} 100 \%}{T}$

After calculating the $\mathrm{X}$ and $\mathrm{Y}$ axis, the next step is input the $\mathrm{X}$ and $\mathrm{Y}$ axis into the EPD matrix. The EPD matrix will generate 4 categories, there are rising star, falling star, lost opportunity and retreat. The EPD matrix served on Table 3 .

After inputing the $\mathrm{X}$ and $\mathrm{Y}$ axis value to the EPD matrix, 4 market categories will be generated. Those are rising star, falling star, lost opportunity, and retreat. According to Esteurizen (2006), rising star is the most ideal market position among the others. It indicates that a country achieves high market share in dynamic products (demand is growing fast). Otherwise, lost opportunity become the less ideal market position, because it indicates that a country loses market share in a dynamic product.

Table 3. EPD matrix (Bappenas, 2009)

\begin{tabular}{ccc}
\hline Share of country's export in & \multicolumn{2}{c}{ Share of product in the world trade $(\mathrm{y})$} \\
\cline { 2 - 3 } world trade $(\mathrm{x})$ & Rising/ Dynamic $(+)$ & Falling/ Stagnant $(-)$ \\
\hline Rising/ competitive $(+)$ & Rising Star & Falling star \\
Falling/non competitive $(-)$ & Lost opportunity & Retreat \\
\hline
\end{tabular}

EPD analysis also used by Hasibuan, 2012 in his research to his analysis of Indonesia's cocoa beans and processed cocoa products competitiveness to the international market. Another researcher that used EPD for competitiveness analysis was Wardani, 2017 to analyzing the export dynamic of Indonesian tire.

\section{RESULTS AND DISCUSSIONS}

1. Comparative and competitive advantage of Indonesia's turmeric compared to competing countries

Based on the RCA estimates listed in Table 4, the RCA value of Indonesian turmeric occupies the fourth position after Ethiopia, Myanmar, and India. Although the results of the RCA of Indonesian turmeric in the international market show that Indonesia's turmeric exports are strong, the RCA value of Indonesian turmeric exports is still relatively small.

These results were in line with Kanaya's research which shows that turmeric and agarwood are biopharmaceutical commodities that are highly competitive in their destination countries compared to other biopharmaceutical plants and competing countries.

Table 4. The result of average RCA value and EPD position in Indonesia and competitor countries from 2009-2019 (International Moneytory Fund, 2021)

\begin{tabular}{clcc}
\hline No. & \multicolumn{1}{c}{ Countries } & Average RCA Value & EPD position \\
\hline 1 & India & 106,29 & Falling Star \\
2 & Myanmar & 71,60 & Rising Star \\
3 & Netherland & 42,01 & Falling Star \\
4 & Vietnam & 3,30 & Rising Star \\
5 & China & 3,022 & Lost Opportunity \\
6 & United Kingdom & 0,90 & Falling Star \\
7 & Ethiopia & 0,59 & Rising Star \\
8 & Germany & 0,16 & Falling Star \\
9 & Indonesia & 0,13 & Falling Star \\
\hline
\end{tabular}

Table 4 also shows that Indonesia's turmeric achieved the falling star position along with the countries of India, Netherland, United Kingdom, and Germany. There are only two countries that occupied the rising 
star position, Myanmar and Ethiopia. Meanwhile China was the only country that occupied lost opportunity position.

The results of EPD analysis shows that there was an increase for the market share of Indonesia's, but the demand for the product was decreasing.

2. Comparative and competitive advantage of Indonesia's turmeric to the main destinated countries

Based on the results of the EPD analysis, Indonesia does not have a rising star position in the seven destination countries. The highest position achieved by Indonesia in its destination country was falling star in India, Singapore, South Korea, and Taiwan. This indicates that India, Singapore, South Korea, and Taiwan have an increasing share of the country's export market, but a decrease in the share of certain products in world trade.

Another study by Kanaya (2014), states that Indonesia's position has been a rising star in India, Malaysia, Singapore, and the Netherlands and a falling star in Japan, Hong Kong, and Saudi Arabia in 2003-2012. This suggests that the decrease in turmeric Indonesian market position in the destination country, which is caused by the increase in the country's export market share, but a decline in the share of certain products in world trade during the years 2009-2019.

Table 3. The result of Indonesia's average RCA value and EPD position to the destinated countries from 2009-2019

\begin{tabular}{rlcc}
\hline No. & \multicolumn{1}{c}{ Imported Countries } & Average RCA Value & EPD Position \\
\hline 1 & India & 9,74 & Falling star \\
2 & Malaysia & 0,49 & Falling star \\
3 & Singapore & 4,96 & Lost Opportunity \\
4 & United States of America & 2,22 & Retreat \\
5 & Korea, Republic of & 4,45 & Retreat \\
6 & Vietnam & 29,52 & Falling star \\
7 & Taipei, Chinese & 7,20 & Falling star \\
\hline
\end{tabular}

From the results of the RCA and EPD analysis that has been done, Indonesian turmeric exports can be said to be competitive both in destination countries and international markets. However, it should be noted that the declining market share of certain products can make the competitiveness of Indonesian turmeric decrease and become less competitive. In fact, the international market with turmeric commodities can be a good prospect for Indonesia to export turmeric to the international market considering that Indonesia has the potential to produce export quality agricultural products.

\section{CONCLUSION}

Using RCA approach, it is proved that Indonesia turmeric export has highly competitive in global market. Specific countries such as India, Singapore, Korea, Vietnam, Taiwan, and the US are main target of Indonesia's turmeric export. Using EPD approach, Indonesia' export on turmeric in global market is in falling star position.

\section{REFERENCES}

Apriansyah, B., \& Sohibien, G. P. (2019). Analisis Daya Saing Karet Alam Indonesia dan Variabel-Variabla Yang Mempengaruhinya. Jurnal Universitas Muhammadiyah Semarang. Vol.7, No. 2, November 2019. Pp: $147-156$

Bappenas. (2009). Perdagangan dan Investasi di Indonesia : Sebuah Catatan tentang Daya Saing dan Tantangan ke Depan. Retrieved from www.bapennas.go.id

Basri, F., \& Munandar, H. (2010). Dasar-Dasar Ekonomi Internasional : Pengenalan \& Aplikasi Metode Kuantitatif. Jakarta: Kencana. 
Penulis : Ni Desak Gede dkk Competitiveness of Indonesia’s Turmeric Commodity ....

BPS. (2010-2019). Statistik Tanaman Biofarmaka Indonesia. Jakarta: Badan Pusat Statistik Indonesia.

Esteurizen. (2006). Measuring and Analysing Competitiveness in The Agribusiness Sector ; Methodological and Analytical Framework. Pretoria: University of Pretoria.

Hasibuan, A. M., Nurmalina, R., \& Wahyudi, A. (2012). Analisis Kinerja Daya Saing Perdagangan Biji Kakao dan Produk Kakao Olahan Indonesia di Pasar Internasional. Jurnal Tanaman Industri dan Penyegar. Vol 3 No 1, Februari 2012: pp: 57-70

International Monetary Fund. (2021). International Monetary Fund. Retrieved from IMF Country Information: https://www.imf.org/en/Countries

Kanaya, I. A., \& Firdaus, M. (2015). Daya Saing dan Permintaan Ekspor Produk Biofarmaka Indonesia di Negara Tujuan Utama Periode 2003-2012. Jurnal Manajemen dan Agribisnis. Vol. 11, No.3, November 2014. pp: 183-198

Listyana, N. H. (2018). Analisis Keterkaitan Produksi Kunyit di Indonesia dan Faktor-Faktor yang Mempengaruhinya. Caraka Tani. Vol. 33, No.2, September 2018.

Putra, H. T., Muhaimin, A. W., \& Suhartini. (2015). The Competitiveness Analysis of Indonesia's Tobacco in The International Market. Habitat. Vol. 26, No.1, April 2015.pp: 57-60

Tambunan, T. (2001). Perekonomian Indonesia. Jakarta: Ghalia Indonesia.

Utami, N. M., D, D. P., \& Dewi , R. K. (2018). Analisis Daya Saing dan Faktor-Faktor yang Mempengaruhi Ekspor Kopi Indonesia di Pasar Internasional. Jurnal Manajemen Agribisnis. Vol. 6, No. 1, December 2018. pp: 8-14

Wardani, M. A., \& Mulatsih, S. (2017). Analisis Daya Saing dan Faktor-Faktor yang Mempengaruhi Ekspor Ban Indonesia ke Kawasan Amerika Latin. Jurnal Ekonomi dan Kebijakan Pembangunan. Vol. 6, No. 1 , hlm. 81-100. pp -81-100

Yolandika, C., Nurmalina, R. and Suharno, S. (2017) 'Rantai Pasok Brokoli di Kecamatan Lembang Kabupaten Bandung Barat dengan Pendekatan Food Supply Chain Networks', Jurnal Penelitian Pertanian Terapan, 16(3), pp. 155-162. doi: 10.25181/jppt.v16i3.93.

Zamroni, S., \& Munadi, E. (2017). Info Komoditi Tanaman Obat. Jakarta: Badan Pengkajian dan Pengembangan Perdagangan.

Zuhdi, F., \& Suharno. (2015). Analisis Daya Saing Ekspor Kopi Indonesia dan Vietnam di Pasar ASEAN 5. Jurnal Habitat. Vol.26, No. 3, December 2015. pp: 152-16 